\title{
MODIFIKASI PEMBELAJARAN PENDIDIKAN JASMANI
}

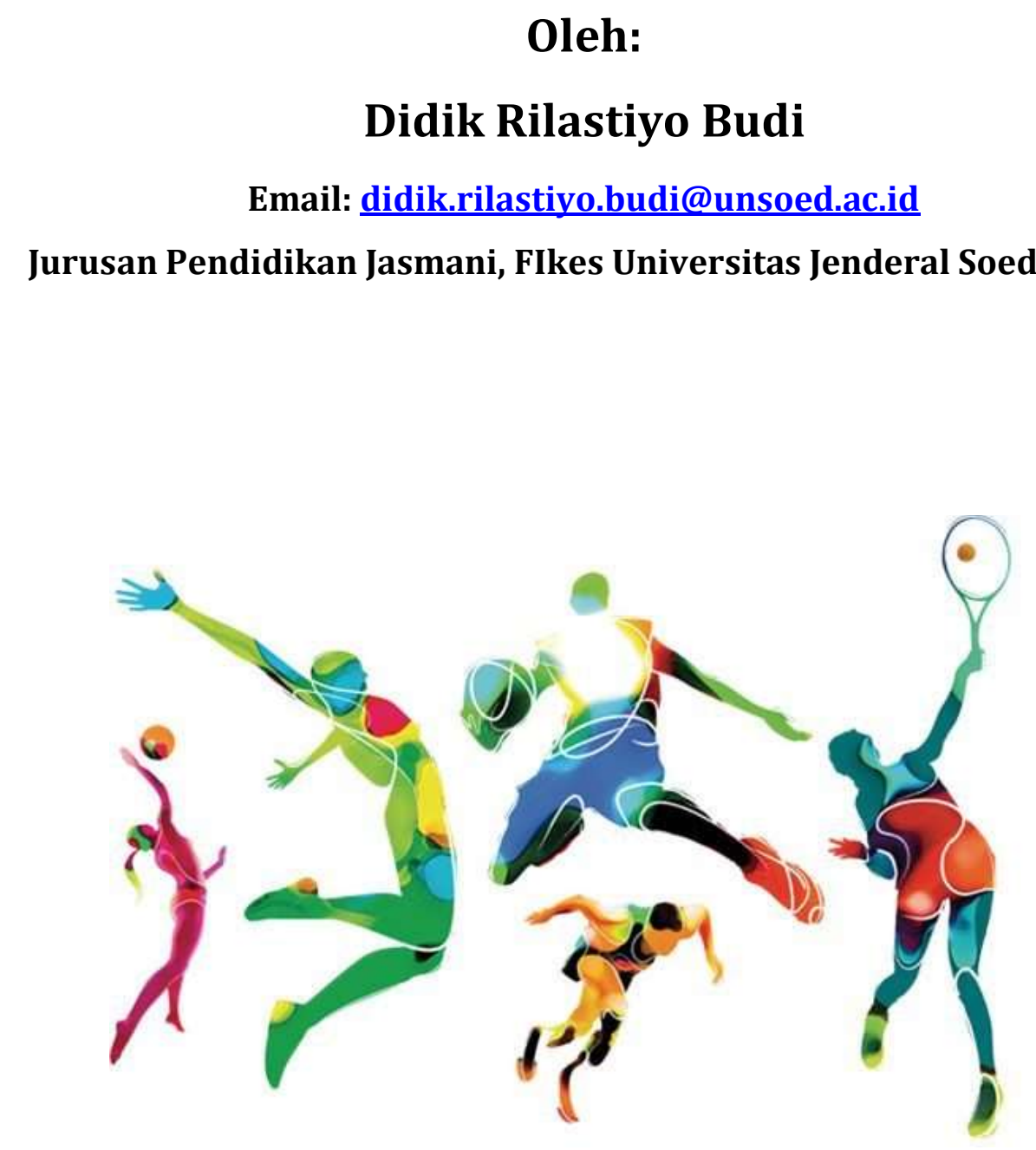

Tahun 2021 


\begin{abstract}
ABSTRAK
Pembelajaran pendidikan jasmani selama ini identik dengan proses belajar keterampilan gerak dengan menggunakan peralatan olahraga yang sebenarnya. Penggunaan peralatan olahraga yang terstandar, tidak jarang menjadi salah satu hambatan dalam pelasanaan pembelajaran penjas yang efektif dan efisien, hal ini dikarenakan tidak semua sekilah memiliki peralatan dan perlengkapan yang memadai. Merujuk dari permasalahan keterbatasan peralatan yang menyebabkan pembelajaran pendidikan jasmani di sekolah kurang berjalan dengan baik, maka dalam perkembangannya kehadiran inovasi dan modifikasi dalam proses pembelajaran penjas menjadi hal yang penting. Dalam makalah ini akan diulas mengenai pengertian modifikasi dan implementasinya dalam pembelajaran penjas di sekolah.
\end{abstract}

Kata Kunci: Modifikasi Pembelajaran, Pendidikan Jasmani, Sekolah 


\section{BAB I}

\section{PENDAHULUAN}

Modifikasi pembelajaran pendidikan jasmani menjadi hal yang penting untuk diketahui oleh para guru pendidikan jasmani disetiap jenjang pendidikan, yang dimulai dari Sekolah Dasar (SD), Sekolah Menengah Pertama (SMP) dan Sekolah Menengah Atas (SMA). Diharapkan dengan guru penjas dapat menjelaskan mengenai konsep dan pengertian modifikasi, menyebutkan apa yang dimodifikasi dan bagaimana cara memodifikasinya, menyebutkan dan menerangkan beberapa aspek analisis modifikasi maka pembelajaran dapat berjalan dengan lebih aktif, efektif dan efisien.

Dalam pelaksanaan program pendidikan jasmani di sekolah hendaknya mencerminkan karakteristik program pendidikan jasmani itu sendiri, yaitu mengedepankan prinsip "Developentally Appropriate Practice" (DAP). DAP Artinya bahwa tugas ajar/gerak yang disampaikan harus memerhatikan perubahan kemampuan atau kondisi anak, dan dapat membantu mendorong kearah perubahan tersebut. Dengan demikian maka dalam belajar gerak atau belajar melalui gerakan harus disesuaikan dengan pertumbuhan dan perkembangan anak/peserta didik. Perkembangan atau kematangan yang dimaksud mencakup fisik, psikis maupun keterampilannya.

Berdasarkan inti dari pembelajaran pendidikan jasmani yang berfokus pada prinsip DAP maka, dalam pelaksanaan proram pembelajaran penjas perlu adanya modifikasi pembelajaran. Modifikasi pembelajaran bertujuan untuk mempermudah siswa belajar menguasai keterampilan gerak, membuat siswa merasa senang selama mengikuti pembelajaran dan membantu mencapai tujuan belajar yang telah ditetapkan oleh guru. Modifikasi pembelajaran yang dapat dilakukan oleh guru meliputi modifikasi materi pembelajaran, modifikasi peralatan pembelajaran, modifikasi sarana pembelajaran, modifikasi aturan pembelajaran dan sebagainya.

Salah satu modifikasi permainan dan sarana pembelajaran yang dapat digunakan dalam pemeblajaran penjas di sekolah, khusunya di SMP dan SMA yaitu modifikasi permainan VOBAS. Dalam permainan Vobas terdapat unsur modifikasi peralatan, lapangan dan jenis serta peraturan permainan sehingga dapat membantu guru untuk mendesain pembelajran dengan lebih menarik. 


\section{BAB II}

\section{MODIFIKASI PEMBELAJARAN PENDIDIKAN JASMANI}

\section{A. Pembelajaran Pendidikan Jasmani}

Pendidikan jasmani secara umum dapat diartikan sebagai pendidikan melalui aktivitas jasmani, permainan atau olahraga yang terpilih untuk mencapai tujuan yang ingin dicapai. Menurut Suherman (2009) dan Budi, et al. (2019) menjelaskan bahwa Pendidikan jasmani adalah pendidikan yang mengaktualisasikan potensi-potensi aktivitas manusia berupa sikap, tindak dan karya yang diberi bentuk, isi, dan arah menuju kebulatan pribadi sesuai dengan cita-cita kemanusiaan. Lebih lanjut menurut Barrow dalam Abduljabar (2011) menerangkan bahwa:

Pendidikan Jasmani dapat didefinsikan sebagai "pendidikan tentang dan melalui gerak insani ketika tujuan kependidikan dicapai melalui media aktivitas otot-otot, termasuk: olahraga (sport), permainan, senam, dan latihan (exercise). Hasil yang ingin dicapai...individu yang terdidik secara fisik. Nilai ini menjadi salah satu bagian nilai individu yang terdidik, dan bermakna hanya ketika berhubungan dengan sisi kehidupan individu.

Dari penjelasan di atas, jelas bahwa kontribusi Penjas hanya akan bermakna ketika pengalaman-pengalaman dalam Penjas berhubungan dengan proses kehidupan sesorang secara utuh. Manakala pengalaman Penjas tidak memberikan kontribusi pada pengalaman kependidikan lainnya, maka pasti terdapat kekeliruan dalam pelaksanaan program penjas (Budi et al., 2020; Nur et al., 2020; Suhartoyo et al., 2019).

Kebermaknaan pada proses pembelajaran penjas akan terwujud apabila guru memahami tentang tujuan yang ingin dicapai dari pendidikan jasmani, dan mengaplikasikannya kepada siswa dalam pembelajaran. Bucher dalam Suherman (2009) menjelaskan bahwa tujuan pendidikan jasamni mencakup empat aspek yaitu::

1) Perkembangan fisik. Tujuan ini berhubungan dengan kemampuan melakukan aktivitas-aktivitas yang melibatkan kekuatan-kekuatan fisik dari beberapa organ tubuh seseorang (physical fitness).

2) Perkembangan gerak. Tujuan ini berhubungan dengan kemampuan melakukan gerak secara efektif, efisien, halus, indah, sempurna (skillful).

3) Perkembangan mental. Tujuan ini berhubungan dengan kemampuan berfikir dan menginterpretasikan keseluruhan pengetahuan tentang pendidikan jasmani ke dalam lingkungannya. 
4) Perkembangan sosial. Tujuan ini berhubungan dengan kemampuan siswa dalam menyesuaikan diri pada suatu kelompok atau masyarakat.

Dalam rangka membantu terlaksananya proses pembelajaran penjas, terutama dalam pembelajaran olahraga permainan walaupun dengan fasilitas pembelajaran yang kurang mendukung, namun proses pembelajaran tetap harus diberikan dan dilaksanakan sesuai kurikulum. Pembelajaran penjas yang efektif terermin apabila siswa dapat terlibat aktif selama pembelajaran dan siswa dapat memperoleh pengalaman sukses serta memuaskan dalam setiap kegiatan belajar (Budi, Hidayat, et al., 2019).

Program pembelajaran pendidikan jasmani yang diberikan kepada siswa hendaknya memperhatikan tingkat pertumbuhan dan perkembangan kemampuan siswa, sehingga pembelajaran efektif dan pengalaman sukses dapat diperoleh oleh siswa (Budi, 2015; Sayfei et al., 2020). Mengenai hal tersebut Bahagia \& Suherman (2000) menjelaskan bahwa:

Penyelenggaraan program pendidikan jasmani hakekatnya mencerminkan karakteristik program pendidikan jasmani itu sendiri, yaitu:"Developmentaly Appropriate Practice" (DAP), artinya adalah tugas ajar yang diberikan harus memperhatikan perubahan kemampuan anak dan dapat membantu mendorong perubahan tersebut. Dengan demikian tugas ajar tersebut harus sesuai dengan tingkat perkembangan anak didik yang sedang belajarnya.

Pembelajaran penjas yang diarahkan dan disesuaikan dengan tingkat perkembangan kemampuan siswa akan memberikan hasil positif bagi siswa, baik dalam perkembangan kemampuan motorik maupun kepribadian siswa (Kusnandar et al., 2019; Listiandi et al., 2020; Setiawan et al., 2020). Selain itu pembelajaran penjas yang didukung dengan inovasi dan modifikasi pembelajaran yang tepat, terutama dengan memodifikasi olahraga permainan dapat memberikan kontribusi yang baik terhadap proses pembelajaran.

\section{B. Tujuan Pendidikan Jasmani}

Tujuan pembelajaran secara umum adalah pembelajaran yang efektif ditandai dengan terjadinya proses belajar dalam diri siswa. Pembelajaran yang berhasil 
menurut Daryanto \& Tasrial (2012) Seseorang dikatakan telah mengalami proses belajar apabila didalam dirinya telah terjadi perubahan, dari tidak tahu menjadi tahu, dari tidak mengerti menjadi mengerti, dan sebagainya.

Dalam memfasilitasi proses belajar anak yang menuju kearah positif dan kondusif, guru perlu mengupayakan melalui kreativitas dengan memvariasikan strategi dalam kegiatan mengajarnya dengan memilih metode yang baik akan merangsang siswa akan selau ingin terlibat dalam pembelajaran dan menuju pembelajran yang efektif ke depanya yang dikemukakan Yusuf (2017) Menjelaskan bahwa ada enam ciri pembelajaran yang efektif, yaitu:

1) Siswa menjadi pengkaji yang aktif terhadap lingkungannya melalui mengobservasi, membandingkan, menemukan kesamaan-kesamaan dan perbedaan - perbedaan serta membentuk konsep dan generalisasi berdasarkan kesamaan-kesamaan yang ditemukan.

2) Guru menyediakan materi sebagai fokus berpikir dan berinteraksi dalam pelajaran, aktivitas - aktivitas siswa sepenuhnya didasarkan pada pengkajian.

3) Guru secara aktif terlibat dalam pemberian arahan dan tuntunan kepada siswa dalam menganalisis informasi.

4) Orientasi pembelajaran penguasaan isi pelajaran dan pengembangan keterampilan berpikir, serta.

5) Guru menggunakan teknik mengajar yang bervariasi sesuai dengan tujuan dan gaya mengajar guru

Sedangkan dalam proses pembelajaran penjas menurut (Lutan, 2001) bertujuan untuk

Tujuan pendidikan jasmani adalah untuk: (1) mengembangkan pengetahuan dan keterampilan yang berkaitan dengan aktivitas jasmani, perkembangan estetika dan perkembangan sosial, (2) membangun kepercayaan diri dan kemampuan untuk menguasai keterampilan gerak dasar yang akan mendorong partisipasinya dalam aneka aktivitas jasmani, (3) memperoleh dan mempertahankan derajat kebugaran jasmani yang optimal untuk melaksanakan tugas sehari-hari secara efisien dan terkendali, (4) mengembangkan nilai-nilai pribadi melalui partisipasi dalam aktivitas jasmani baik secara berkelompok maupun perorangan, (5) berpartisipasi dalam aktivitas jasmani yang dapat mengembangkan keterampilan sosial yang memungkinkan siswa berfungsi secara efektif dalam hubungan antar orang, (6) menikmati kesenangan dan keriangan melalui aktivitas jasmani, termasuk aktivitas olahraga.

Dalam pembelajaran penjas, guru harus pandai mengunakan pendekatan secara arif dan bijaksana, bukan sembarangan yang bisa merugikan anak didik. Pandangan 
guru terhadap anak didik akan menentukan sikap dan perbuatan. Setiap guru tidak selalu mempunyai pandangan yang sama dalam menilai anak didik. Hal ini akan mempengaruhi pendekatan yang guru ambil dalam pengajaran.

Guru yang memandang anak didiknya sebagai pribadi yang berbeda dengan anak didik lainya akan berbeda dengan guru yang memandang anak didik sebagai mahluk yang sama dan tidak ada perbedaan dalam segala hal. Maka adalah penting meluruskan pandangan yang keliru dalam menilai anak didik. Sebaiknya guru memandang anak didiknya sebagai individu dengan segala perbedaanya.

\section{Modifikasi Dalam Pembelajaran Penjas}

Setiap pembelajaran yang di dalamnya memiliki materi pembelajaran, akan selalu berkembang dari waktu ke waktu. Proses perkembangan tersebut akan selalu membutuhkan inovasi dan modifikasi sebagai penunjang kesuksesan proses pembelajaran. Pembelajaran penjas yang merupakan pembelajaran dengan menggunakan aktifitas fisik dan praktik langsung di lapangan juga memerlukan adanya modifikasi. Siedentop (1991) dalam Suherman (2009) menjelaskan bahwa:

This does not suggest that teaching can or should be viewed as a mechanistic enterprise. Not does it suggest that there is no room in effective teaching for personal style, inventiveness, intuition. Effective teachers artistically orchestrate a set off highly developed skills to meet the specific demands of a learning setting.

Modifikasi secara umum dapat diartikan sebagai usaha untuk mengubah atau menyesuaikan. Namun secara khusus modifikasi adalah suatu upaya yang dilakukan untuk menciptakan dan menampilkan sesuatu hal yang baru, unik, dan menarik tanpa menghilangkan unsur-unsur pokok dari apa yang dimodifikasi.

Bahagia \& Suherman (2000) menjelaskan bahwa Modifikasi juga tidak terfokus pada satu arah saja, tetapi ada modifikasi modifikasi tujuan pembelajaran, modifikasi materi pembelajaran, modifikasi kondisi lingkungan pembelajaran dan modifikasi evaluasi pembelajaran. Oleh karena itu dalam melakukan modifikasi pembelajaran penjas, guru harus memperhatikan prinsip modifikasi, sehingga proses pembelajaran tetap dapat diikuti siswa karena sesuai dengan perkembangan kemampuan motorik siswa. Mengenai hal tersebut, (Bahagia \& Suherman, 2000) menjelaskan bahwa: 
Untuk mempermudah melakukan pengembangan dan modifikasi dalam pembelajaran penjasorkes, kita mengenal aspek psikomotor yang harus dikembangkannya (misalnya kesegaran jasmani dan skill). Dalam pembelajaran kesegaran kita kenal komponennya (misalnya kekuatan dan fleksibilitas). Dalam pembelajaran skill kita kenal klasifikasinya (misalnya open dan close skill). Dalam pembelajaran konsep gerak kita kenal klasifikasinya (misalnya prinsip dan kualitas gerak).

Apabila guru telah mengetahui karakteristik materi dalam pendidikan jasmani, maka proses modifikasi dapat berjalan secara efektif. Guru melakukan modifikasi dalam pembelajaran tentunya mempunyai tujuan yang ingin dicapai. Secara umum tujuan yang ingin dicapai oleh guru dengan melakukan modifikasi pembelajaran, terutama pembelajaran olahraga permainan yaitu untuk mengefektifkan waktu pembelajaran, untuk menanggulangi minimnya perlengkapan dan peralatan pembelajaran serta mempermudah siswa untuk memahami proses belajar gerak yang diajarkan guru (Agustan et al., 2020; Budi, 2015).

Eaves et al., 2008a; Gréhaigne and Godbout, 1998; Kew, 1990; Usabiaga and Castellano, 2005 dalam Arias et al. (2011) menjelaskan bahwa : Along with the complexity of all the variables that interact in the game, this makes it more difficult to determine the implications of rule modification. Yang artinya modifikasi memiliki tujuan mendasar yaitu memudahkan beberapa permainan yang diberikan tanpa kehilangan konsep dasar yang ada

Modifikasi pembelajaran dapat dikaitkan pula dengan tujuan pembelajaran, dari mulai tujuan yang paling rendah sampai dengan tujuan yang paling tinggi. Modifikasi tujuan pembelajaran ini dapat dilakukan dengan cara membagi tujuan pembelajaran ke dalam tiga komponen yakni: tujuan perluasan, tujuan penghalusan dan tujuan penerapan (Bahagia \& Suherman, 2000).

Pertama adalah tujuan perluasan maksudnya adalah tujuan pembelajaran yang lebih menekankan pada perolehan pengetahuan dan kemampuan melakukan bentuk atau wujud keterampilan yang dipelajarinya tanpa memperhatikan aspek efisiensi atau efektifitasnya. Kedua adalah tujuan penghalusan maksudnya adalah tujuan pembelajaran yang lebih menekankan pada perolehan pengetahuan dan kemampuan melakukan gerak secara efisien. Ketiga adalah tujuan penerapan maksudnya tujuan 
pembelajaran yang lebih menekankan pada perolehan pengetahuan dan kemampuan tentang efektif tidaknya gerakan yang dilakukan melalui kriteria tertentu sesuai dengan tingkat kemampuan siswa.

Dengan pola modifikasi tersebut maka, diharapkan dapat mempermudah siswa untuk belajar gerak dan belajar melalui gerakan dalam pembelajaran penjas. Apabila siswa dapat belajar dengan baik maka siswa dapat meningkatkan komponen keterampilan gerak, kebugaran dan kerjasama untuk menunjang pertumbuhan dan perkembangan dalam dirinya.

\section{Modifikasi Permainan VOBAS (Voli-Basket-Sepak Bola)}

\section{Definisi Permainan VoBAS (Voli-Basket-Sepak Bola)}

Permainan VOBAS (Voli-Basket-Sepak Bola) merupakan jenis permainan baru yang dikembangkan di Indonesia, dan bertujuan untuk memberikan variasi pembelajaran olahraga permainan kepada siswa. Permainan VOBAS (Voli-BasketSepak Bola) pada hakekatnya merupakan hasil penggabungan dari permainan bola voli, bola basket dan sepak bola (Budi, 2015; Stephani et al., 2018).

Kemenpora (2013) menjelaskan bahwa: Permainan VOBAS merupakan permainan yang menggabungkan ketiga gerak dasar dalam pembelajaran permanian bola besar, yaitu bola voli, bola basket dan sepak bola dalam suatu bentuk permainan. Karena VOBAS meruapakan olahraga permainan hasil dari penggabungan, maka VOBAS dapat dimainkan dalam satu lapangan yang dimodifikasi, dan didalamnya terdapat lapangan bola voli, bola basket dan sepak bola.

Target dan sasaran dalam permainan VOBAS terdiri dari gawang dan ring yang digunakan oleh setiap tim. Setiap tim terdiri dari 4 sampai 6 orang peserta didik. Jumlah peserta didik atau anggota tim dalam permainan ini disesuaikan dengan jenis atau luas lapangan permainan yang tersedia. Bola yang digunakan dalam permainan VOBAS adalah bola voli, bola plastik, bola karet atau bola mainan yang mudah ditemukan dan dibeli di toko atau warung (Kemenpora, 2013). 


\section{Fasilitas dan Alat yang Digunakan}

\section{a. Lapangan Permainan VOBAS}

Seperti halnya olahraga permainan yang lain, permainan VOBAS juga memerlukan lapangan yang dapat digunakan dalam permainan. Karena permainan VOBAS merupakan jenis olahraga permainan hasil dari pengembangan olahraga bola voli, bola baskt dan sepak bola maka, di dalam lapangan permainan VOBAS terdiri dari tiga lapangan dalam satu tempat.

Mengenai lapangan permainan, Kemenpora (2013) menjelaskan bahwa: Permainan VOBAS dibagi menjadi tiga area yaitu area untuk memainkan permainan bola voli, bola basket dan sepak bola. Kemudian mengenai luas lapangan yang digunakan dalam Permainan VOBAS tidak ada ukuran baku, karena mengacu pada prinsip modifikasi, Kemenpora (2013) menjelaskan bahwa: Prinsip pembagian luas area di dalam lapangan permainan VOBAS disesaikan luas lapangan yang tersedia dengan komposisi yang sama.

Untuk lebih jelas mengenai bentuk lapangan permainan VOBAS dan bagaimana Pembagian wilayah lapangan permainan dapat dilihat pada gambar lapangan sebagai berikut:

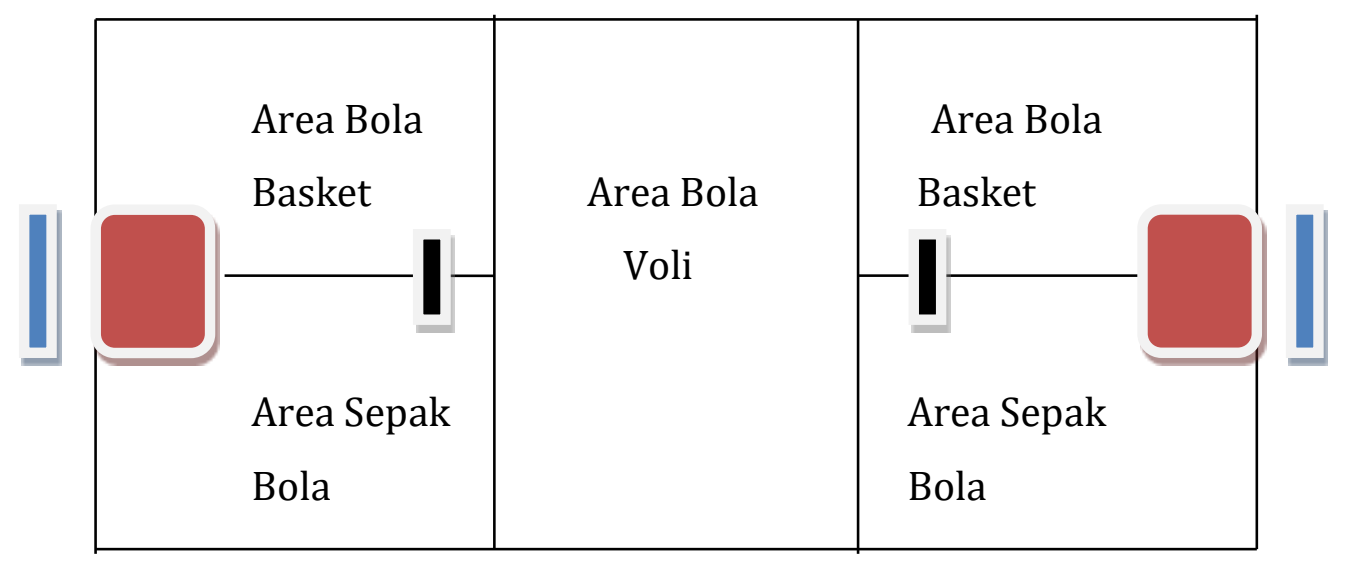

Gambar 1

Lapangan Permainan VOBAS (Sumber, Kemenpora, 2013) Keterangan

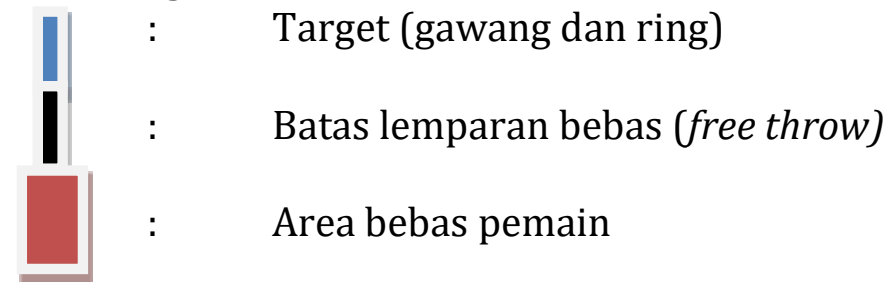




\section{b. Gawang dan Ring}

Gawang dan ring dalam permainan VOBAS berfungsi sebagai target bagi siswa untuk dapat membuat skor dalam permaian. Mengenai ukuran gawang dan ring yang digunakan dalam permainan, Kemenpora (2013) menjelaskan sebagai berikut:

1. Setiap tim memiliki target sasarn berupa gawang dan ring sebagai sasaran untuk mencetak point.

2. Gawang menjadi sasaran mencetak poin bagi peserta didik ketika berada pada area sepak bola dan bola voli.

3. Gawang mempunyai ukuran lebar $120 \mathrm{~cm}$ dan tinggi $75 \mathrm{~cm}$.

4. Ring menjadi sasaran mencetak point bagi peserta didik ketika berada pada area bola basket dan area bola voli.

5. Ring berjumlah dua buah yaitu 1 ring dengan posisi vertikal(menghadap ke depan) dan 1 ring dengan posisi horisontal (menghadap ke atas) dengan diameter sebesar $50 \mathrm{~cm}$,

6. Gawang dan ring dibuat menjadi satu rangkaian, artinya terdiri dari tiga komponen yang digabungkan menjadi satu bentuk yang uruh.

\section{c. Bola Permainan VOBAS}

Bola merupakan alat yang sangat penting dalam permainan VOBAS, karena tanpa adanya bola yang digunakan, maka permainan ini tidak akan berjalan. Kemenpora (2013) menjelaskan mengenai kriteria bola yang dapat digunakan dalam permainan VOBAS

1. Bola yang digunakan dalam permainan Vobas adalah bola voli, bola plastik, bola karet atau bola mainan yang ukurannya hampir menyamai bola voli.

2. Bola dalam permainan VOBAS menggunakan bola yang dapat dipantulkan, nyaman dan tidak menimbulkan rasa sakit saat ditendang, ditangkap maupun saat dipantulkan.

\section{Gerak dan Teknik Dasar Permainan VOBAS}

Gerakan dasar atau teknik dasar pada suatu olahraga permainan, merupakan faktor fundamental yang harus dapat dilakukan sehingga permainan dapat berjalan 
sebagaimana mestinya. Permainan VOBAS juga memiliki teknik dasar yang harus dikuasai oleh siswa selama permaian berlangsung. Pemain yang sedang berada dalam area bola basket, area bola voli maupun area sepak bola diwajibkan bergerak dengan memperhatikan gerak dan teknik dasar yang telah ditetapkan dalam permainan VOBAS (Kemenpora, 2013).

Lebih lanjut mengenai gerak dan teknik dasar yang digunakan dalam permainan VOBAS, (Budi, 2015; Kemenpora, 2013) menjelaskan sebagai berikut:

1. Area bola basket, peserta didik diwajibkan bergerak sesuai gerak dan teknik dasar dalam permainan bola basket, yaitu melempar bola (passing), dan menggiring bola (dribbling).

2. Area bola voli, peserta didik diwajibkan untuk bergerak sesuai gerakan dan teknik dasar bola voli, yaitu servis bawah, passing bawah dan passing atas.

3. Area sepak bola, peserta didik diwajibkan untuk bergerak sesuai gerakan dan teknik dasar sepak bola, yaitu menendang dan menggiring bola.

Karakteristik permainan VOBAS yang menggabungkan tiga olahraga permainan menjadi satu permainan akan membuat siswa melakukan banyak variasi gerakan dalam satu pembelajaran. Semakin banyak siswa mempelajari vasiasi gerakan dasar dalam olahraga permainan diharapkan siswa akan memiliki kekayaan akan berbagai macam teknik dasar, baik teknik dasar sepak bola, bola voli maupun bola basket secara sekaligus.

Teknik dasar yang digunakan pada masing-masing area akan melatih peserta didik untuk mempraktikan materi teknik dasar yang telah dipelajari dalam pembelajaran permainan bola besar melalui aktivitas bermain. Siswa yang dapat menerapkan pola gerak dan teknik dasar permaian VOBAS selama pembelajaran diharapkan dapat mengoptimalkan koordinasi gerak yang mereka miliki, yang pada akhirnya akan memberikan pengalaman gerak yang bermakna kepada peserta didik.

\section{Peraturan Permainan VOBAS}

Sebagaimana jenis olahraga permainan yang lain, permainan VOBAS juga memiliki peraturan permainan yang harus diperhatikan dan dilaksanakan oleh setiap pemain yang terlibat dalam permainan ini. Permainan VOBAS, dimainkan dengan cara dan peraturan yang telah dikembangkan dari ketiga jenis permainan bola besar. 
Peraturan yang diterapkan masih sederhana dengan harapan mudah untuk dipahami oleh peserta didik ketika bermain (Kemenpora, 2013). Peraturan permainan VOBAS adalah:

\section{a. Jumlah pemain}

1) Permainan VOBAS dimainkan oleh 2 tim.

2) Setiap tim terdiri dari 4 sampai 6 peserta didik, dan disarankan tim merupakan gabungan dari pemain putri dan putra.

3) Jumlah peserta didik dalam permainan VOBAS disesuaikan dengan jenis lapangan permainan yang digunakan.

4) Setiap tim terdiri dari empat peserta didik, jika menggunakan lapangan bola voli.

5) Setiap tim terdiri dari lima peserta didik, jika menggunakan lapangan bola basket.

6) Setiap tim terdiri dari enam peserta didik, jika menggunakan setengah lapangan sepak bola.

\section{b. Perlengkapan peserta didik.}

1) Memakai baju olahraga.

2) Memakai celana olaharaga pendek.

3) Memakai kaos kaki.

4) Memakai sepatu olahraga.

\section{c. Waktu bermain dan permulaan permainan}

1) Permainan VOBAS terdiri dari 2 babak dimana setiap babak dimainkann selama 10 meneit.

2) Permulaan permaian dimulai dari area bola voli dimana dua peserta di area bola voli selanjutnya salah satu peserta didik melakukan lemparan, peerta didik yang lain melakukan passing bola voli (passing bawah maupun atas) yang diarahkan kepada peserta didik satu tim yang berada pada area sepak bola maupun area bola basket

3) Permulaan permainan dilakukan dengan ketentuan jika peserta didik tim melakukan permulaan permainan berada di area bola voli maka peserta didik tim lain tidak boleh berada di arae yang sama (area bola voli).. 
4) Permulaan permaian dilakukan oleh dua orang peserta didik dari setiap tim dimana pada permulaan permainan selanjutnya harus dilakukan oleh peserta didik yang lain (bergantian) hingga semua peserta didik dalam satu tim melakukan permulaan permainan kemudian kembali lagi kepada orang pertama untuk kesempatan kedua untuk melakukan permulaan permainan.

5) Jika tercipta point maka, permaian dihentikan dan dimulai kembali melalui permainan oleh tim yang kemasukan bola (gawang dan ring).

\section{d. Area bebas pemaian (Free area)}

1) Area bebas pemain (Free area) adalah area yang tidak boleh dimasuki oleh peserta didik, baik peserta didik bertahan maupun peserta didik penyerang.

2) Area bebas pemain dibuat dengan tujuan agar peserta didik bertahan tidak menutupi target sasaran (gawang atau ring) ketika peserta didik penyerang melakukan tembakan (shooting). Sebaliknya dengan adanya area bebas pemain, peserta didik penyerang tidak terlalu mudah untuk mencetak point karena adanya batasan jarak untuk melakukan tembakan.

3) Area bebas pemain berada di depan target dengan luas area 2 meter $\times 2$ meter.

\section{e. Cara mencetak point}

1) Suatu point dicetak jika bola masuk ke target sasaran yaitu gawang maupun ring disesuaikan darimana peserta didik melakukan tembakan. Jika peserta didik berada di area basket maka tarket sasaran adalah ring, jika peserta didik berada di area sepak bola maka target sasaran adalah gawang, dan jika peserta didik berada di area bola voli maka target sasaran adalah gawang dan ring.

2) Setiap tim yang memasukan bola ke dalam target sasran (gawang dan ring) akan mendapat point 1 .

3) Tim yang mengumpulkan jumlah point terbanyak selama permainan VOBAS berlangsung dianggap sebagai pemenang pertandingan. 


\section{E. Perbedaan Karakteristik Permainan Vobas dengan Permainan Bola Voli, Bola Basket dan Sepak Bola}

Pembelajaran olahraga permainan, menjadi materi wajib yang harus diajarkan di Sekolah Menengah Pertama (SMP) dan Sekolah Menengah Atas (SMA/SMK). Salah satu materi olahraga permainan yang diajarkan di SMP dan SMA/SMK yaitu olahraga permainan bola besar, yang meliputi Bola Voli, Bola Basket dan Sepak Bola. Pembelajaran olahraga permainan diajarkan kepada siswa dengan tujuan untuk mengembangkan aspek kognitif, afektif dan psikomotor. Hal ini tercantum dalam Kopetensi Inti (KI) dan Kompetensi Dasar (KD) kurikulum KTSP 2006 dan Kurikulum 2013 yang menyebutkan Mempraktikan kombinasi teknik dasar salah satu permainan dan olahraga beregu bola besar lanjutan dengan baik serta nilai kerjasama, toleransi, percaya dini, keberanian, menghargai lawan, bersedia berbagi tempat dan peralatan

Secara tujuan afektif atau sikap, pembelajran olahraga permainan Vobas dan pembelajaran bola voli, bola basket, dan sepak bola secara konvensional memiliki tujuan yang relatif sama, yaitu salah satunya untuk mengembangkan sikap kerjasama dalam diri siswa. Hal ini dikarenakan karakteristik olahraga permainan tersebut merupakan olahraga beregu atau kelompok sehingga membutuhkan kerjasama dalam permainannya. Walupun sama-sama memerlukan kerjasama antar kelompok, pembelajaran permainan Vobas dengan pembelajaran olahraga permainan bola voli, bola basket, dan sepak bola konvensional pada dasarnya memiliki karakteristik permainan yang berbeda dalam proses pembelajarannya.

\section{Tabel 1}

Perbedaan karakteristik pembelajaran permainan Vobas dengan pembelajaran permainan bola voli, bola basket, dan sepak bola konvensional

\begin{tabular}{|c|l|}
\hline \multicolumn{1}{|c|}{ Pembelajaran Permainan Vobas } & $\begin{array}{l}\text { Pembelajaran Permainan Bola Voli, } \\
\text { Bola Basket, dan Sepak Bola } \\
\text { Konvensional }\end{array}$ \\
\hline $\begin{array}{l}\text { Permainan Vobas merupakan hasil } \\
\text { modifikasi yang menggabungkan } \\
\text { gerakan dari permainan bola voli, } \\
\text { bola basket, dan sepak bola yang } \\
\text { dimainkan dalam satu lapangan } \\
\text { permainan }\end{array}$ & $\begin{array}{l}\text { Pembelajaran permainan bola voli, } \\
\text { bola basket, dan sepak bola } \\
\text { merupakan pembelajaran yang berdiri } \\
\text { sendiri sehingga dimainkan dalam } \\
\text { lapangan yang berbeda }\end{array}$ \\
\hline
\end{tabular}




\begin{tabular}{|c|c|}
\hline $\begin{array}{l}\text { Permainan Vobas yang dimainkan } \\
\text { dalam satu lapangan permainan dan } \\
\text { menggunakan berbagai teknik dasar } \\
\text { yang bervariasi sehingga dapat } \\
\text { membuat siswa lebih aktif bergerak } \\
\text { selama pembelajaran, karena apabila } \\
\text { siswa masih lemah dalam salah satu } \\
\text { teknik dasar dalam permainan Vobas, } \\
\text { maka dia dapat menutupinya dengan } \\
\text { melakukan teknik dasar permainan } \\
\text { yang lainnya, sambil dia tetap belajar } \\
\text { teknik dasar permainan yang masih } \\
\text { lemah. }\end{array}$ & $\begin{array}{l}\text { Karaena pembelajaran permainan } \\
\text { bola voli, bola basket, dan sepak bola } \\
\text { berdiri sendiri dengan berbagai teknik } \\
\text { dasar dan karakteristik di dalamnya, } \\
\text { maka dalam proses pembelajaran } \\
\text { apabila siswa belum menguasai salah } \\
\text { satu teknik dasar permainannya } \\
\text { secara baik dimungkinkan akan } \\
\text { terjadi pembelajaran yang pasif. }\end{array}$ \\
\hline $\begin{array}{l}\text { Dengan menggabungkan ketiga teknik } \\
\text { dasar permainan bola voli, bola } \\
\text { basket, dan sepak bola dalam bentuk } \\
\text { permainan Vobas, maka siswa akan } \\
\text { mendapat kesempatan belajar ketiga } \\
\text { teknik dasar tersebut dalam jumlah } \\
\text { yang relatif banyak, sehingga akan } \\
\text { memberikan pengalaman gerak yang } \\
\text { lebih bermakna bagi siswa }\end{array}$ & $\begin{array}{l}\text { Dalam pembelajara terkadang siswa } \\
\text { tidak memiliki kesempatan belajar } \\
\text { dan bermain dengan jumlah yang } \\
\text { cukup, sehingga siswa kurang } \\
\text { mendapat kesempatan untuk belajar } \\
\text { teknik dasar dan berbagai gerakan } \\
\text { dalam olahraga permainan bola voli, } \\
\text { bola basket, dan sepak bola sehingga } \\
\text { siswa tidak selalu memperoleh } \\
\text { pengalaman gerak yang bermakna }\end{array}$ \\
\hline $\begin{array}{l}\text { Karakteristik yang } \text { terdapat dalam } \\
\text { permainan Vobas memungkinkan } \\
\text { siswa aktif bergerak dan } \\
\text { mendapatkan kesempatan belajar } \\
\text { dengan lebih baik, sehingga } \\
\text { memungkinkan siswa dapat } \\
\text { mengembangkan sikap kerjasama } \\
\text { yang ada dalam diri mereka, karena } \\
\text { proses kerjasama akan terjadi secara } \\
\text { optimal apabila siswa mendapatkan } \\
\text { kesempatan belajar dalam kelompok } \\
\text { dengan waktu yang relatif banyak }\end{array}$ & $\begin{array}{l}\text { Pembelajaran permainan bola voli, } \\
\text { bola basket, dan sepak bola secara } \\
\text { keseluruhan dapat mengembangkan } \\
\text { sikap kerjasama pada siswa, karena } \\
\text { permainan tersebut merupakan } \\
\text { permainan beregu dan dibutuhkan } \\
\text { kerjasama dalam melakukannya. Akan } \\
\text { tetapi, dengan kesempatn bermain } \\
\text { yang relatif tidak sama, maka dalam } \\
\text { mengembangkan sikap kerjasama } \\
\text { dimungkinkan kurang berjalan } \\
\text { optimal }\end{array}$ \\
\hline $\begin{array}{l}\text { Selain kerjasama, karakteristik dalam } \\
\text { permainan Vobas juga diasumsikan } \\
\text { akan memberikan pengaruh positif } \\
\text { dalam peningkatan kebugaran } \\
\text { jasmani siswa, karena permbelajaran } \\
\text { yang aktif dan kaya akan gerak }\end{array}$ & $\begin{array}{l}\text { Pembelajaran permainan bola voli, } \\
\text { bola basket, dan sepak bola secara } \\
\text { keseluruhan dapat meningkatkan } \\
\text { kebugaran jasmani, akan tetapi jika } \\
\text { diajarkan secara tersendiri maka akan } \\
\text { memberikan dampak yang berbeda } \\
\text { dalam peningkatan kebugaran jasmani } \\
\text { siswa }\end{array}$ \\
\hline
\end{tabular}


Dari pemaparan di atas, mengenai perbedaan karakteristik dalam pembelajaran permainan Vobas dan pembelajaran olahraga permainan bola voli, bola basket, dan sepak bola secara konvensional maka diasumsikan pembelajaran permainan Vobas akan jauh lebih efektif dalam meningkatkan kerjasama siswa dibandingkan dengan olahraga permainan bola voli, bola basket dan sepak bola secara konvensional. 


\section{BAB III \\ PENUTUP}

Media pembelajaran dan modifikasi penjas merupakan salah faktor pendukung dalam suksesnya proses belajar mengajar disekolah akan tetapi kurangnya ketersediaan sarana dan prasarana dalam setiap sekolah terkhusus mata pelaran penjas maka seorang guru dituntut untuk lebih kreatif dan memamfaatkan apa yang ada disekitarnya yang diproses atau dimodifikasi sebagai alat pembelajaran, selain itu bagi sekolah yang memiliki sarana prasarana yang memadai bukan berarti bahwa seorang guru tidak memodifikasi sarana prasarana tersebut, akan tetapi dengan peralatan yang memdai dan didukung dengan penerapan pembelajaran penjas modifikasi maka diharapkan dapat meningkatkan keterlibaran siswa dalam pembelajaran.

Salah saru bentuk permainan modifikasi yang dapat digunakan dan diterapkan dalam pembelajaran penjas di sekolaj yaitu modifikasi permainan VOBAS (Voli-BasketSepakbola) yang dimainkan dalam satu lapangan secara bersama-sama. Dengan melakukan permainan Vobas, anak akan secara langsung belajar tiga keterampilan dasar oleharaga permainan secara sekaligus, sehinga selin dapat meningkatkan keterlibatan siswa, permainan Vobas juga dapat melatih kerjasama dan meningkatkan penguasaan keterampilan teknik dasar kepada siswa.

Penulis berharap setelah memahami tentang media yang digunakan dalam proses belajar mengajar disekolah maka kita dapat lebih kreatif dalam penerapan memodifikasi pembelajaran penjas sesuai dengan kebutuhan dan kemampuan anak yang dimiliki, sehingga dapat membantu tercapainya tujuan pembelajaran yang telah ditetapkan. 


\section{DAFTAR PUSTAKA}

Abduljabar, B. (2011). Pengertian pendidikan jasmani. Ilmu Pendidikan.

Agustan, B., Kusmaedi, N., Hendrayana, Y., Abduljabar, B., \& Ginanjar, A. (2020). Modifikasi pembelajaran: hybrid sport education-invasion games competence model terhadap performa permainan bola basket. Jurnal SPORTIF: Jurnal Penelitian Pembelajaran. https://doi.org/10.29407/js_unpgri.v6i1.14005

Arias, J. L., Argudo, F. M., \& Alonso, J. I. (2011). Review of rule modification in sport. In Journal of Sports Science and Medicine.

Bahagia, Y., \& Suherman, A. (2000). Prinsip-Prinsipm Pengembangan dan Modifikasi Cabang Olahraga. DEPDIKBUD.

Budi, D. R. (2015). Pengaruh Modifikasi Permainan Vobas dan Kebugaran Jasmani terhadap Peningkatan Kerjasama Siswa dalam Pembelajaran Penjas di SMP. Thesis. http://repository.upi.edu/id/eprint/17605

Budi, D. R., Hidayat, R., \& Febriani, A. R. (2019). The Application of Tactical Approaches in Learning Handballs. JUARA : Jurnal Olahraga. https://doi.org/10.33222/juara.v4i2.534

Budi, D. R., Kusuma, M. N. H., Syafei, M., \& Stephani, M. R. (2019). The Analysis of Fundamental Movement Skill in Primary School Student in Mountain Range. https://doi.org/10.2991/icsshpe-18.2019.56

Budi, D. R., Listiandi, A. D., Festiawan, R., Widanita, N., \& Anggraeni, D. (2020). Indeks Masa Tubuh (IMT): Kajian Analisis pada Atlet Renang Junior Usia Sekolah Dasar. TEGAR: Journal of Teaching Physical Education in Elementary School, 3(2), 46-53. https://doi.org/10.17509/tegar.v3i2.24452

Daryanto, \& Tasrial. (2012). Konsep pembelajaran kreatif. Psikologi Pendidikan.

Kemenpora. (2013). Permainan VOBAS Media Pembelajaran Olahraga Pendidikan.

Kusnandar, K., Purnamasari, D. U., Nurcahyo, P. J., \& Darjito, E. (2019). Pengaruh Permainan Tradisional Banyumas Gol-Golan Terhadap Tingkat Kebugaran Jasmani Siswa Sekolah Dasar Di Kabupaten Banyumas. Physical Activity Journal. https://doi.org/10.20884/1.paju.2019.1.1.1996

Listiandi, A. D., Kusuma, M. N. H., Budi, D. R., Hidayat, R., Bakhri, R. S., \& Abdurahman, I. (2020). Pemanfaatan Aplikasi Smartphone untuk Meningkatkan Daya Tahan Kardiovaskuler dan Self-efficacy. Jendela Olahraga. https://doi.org/10.26877/jo.v5i2.5442

Lutan, R. (2001). Mengajar Penjas Pendekatan Pendidikan Gerak di Sekolah Dasar. Jakarta: Direktorat Jendral Olaharaga.

Nur, L., Malik, A. A., Juditya, S., Kastrena, E., Widyawan, D., Agustan, B., Budi, D. R., Ardha, M. A. Al, \& Yang, C. B. (2020). Comparison of two types of instruction in physical education. International Journal of Psychosocial Rehabilitation. https://doi.org/10.37200/IJPR/V24I10/PR300205

Sayfei, M., Budi, D. R., Himawan Kusuma, M. N., \& Listiandi, A. D. (2020). Identifikasi Keberbakatan Menggunakan Metode Australian Sport Search Terhadap Kesesuaian Cabang Olahraga Pada Anak Sekolah Dasar. Physical Activity Journal. https://doi.org/10.20884/1.paju.2020.1.2.2285

Setiawan, A., Yudiana, Y., Ugelta, S., Oktriani, S., Budi, D. R., \& Listiandi, A. D. (2020). Hasil Belajar Pendidikan Jasmani dan Olahraga Siswa Sekolah Dasar: Pengaruh Keterampilan Motorik (Tinggi) dan Model Pembelajaran (Kooperatif). TEGAR: Journal 
of Teaching Physical Education in Elementary School. https://doi.org/10.17509/tegar.v3i2.24513

Stephani, M. R., Kamnuron, K., Friskawati, F., Ilmawati, I., \& Sumarno, G. (2018). Implementation of Vobas Game Modification to Student's Self-Esteem in Senior High School. https://doi.org/10.5220/0007068206900694

Suhartoyo, T., Budi, D. R., Kusuma, M. N. H., Syafei, M., Listiandi, A. D., \& Hidayat, R. (2019). Identifikasi Kebugaran Jasmani Siswa SMP Di Daerah Dataran Tinggi Kabupaten Banyumas. Physical Activity Journal. https://doi.org/10.20884/1.paju.2019.1.1.1995

Suherman, A. (2009). Revitalisasi Pengajaran dalam Pendidikan Jasmani. CV. Bintang Warli Artika.

Yusuf, B. B. (2017). Konsep Dan Indikator Pembelajaran Efektif. In Jurnal Kajian Pembelajaran dan Keilmuan. 